\title{
Women On Boards Of Directors: Effects On Firm Social Performance In The Basic Materials And Financial Services Sectors
}

Mel E. Schnake, (Email: mschnake@valdosta.edu), Valdosta State University

Robert J. Williams, (Email: robwill@valdosta.edu), Valdosta State University

William Fredenberger, (Email: bfredenb@valdosta.edu), Valdosta State University

\begin{abstract}
This study examined relationships between the number of female board members, board tenure, and board size on the number of $10 \mathrm{~K}$ investigations that were instigated against firms in the basic materials and financial services sectors of the economy. After controlling for the effects of firm size, we found evidence of an interaction effect between the number of female directors and average board tenure for firms in the financial services sector, such that a higher number of women on boards coupled with longer average board tenure results in higher firm social performance (i.e., the fewer the number of $10 \mathrm{~K}$ investigations brought against the firm). No link was found between female directors and average board tenure for the basic materials firms. Further, no interactive patterns were observed between female directors and board size in either sector. Our findings suggest that future board research may benefit from a "contingency approach," as this study has provided some evidence that the relationships between board characteristics and firm performance may not be generalizable from one sector to another. Future research should carefully consider how the sector or industry may affect the impact of board characteristics on firm performance.
\end{abstract}

\section{INTRODUCTION}

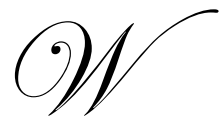

hile men continue to occupy most seats on U.S. firms' boards of directors, Catalyst (1998) reports that U.S. firms lead firms in most other countries, with $86 \%$ of U.S. firms having at least one woman on their boards of directors. However, another important statistic is the percentage of total board seats held by women. This percentage increased only slightly, from $8.3 \%$ in 1993 to $11.1 \%$ in 1998 (Catalyst, 1998).

Researchers suggest several reasons for including women on a firm's board of directors. First, increased diversity of board members may bring a greater pool of resources, knowledge and information for the board to use in fulfilling its responsibilities in representing shareholders' interests (Burgess and Tharenou, 2002; Hillman, Canella and Harris, 2002). Daily, Certo, and Dalton (1999) also point out that women make $60 \%$ of all purchases in the United States and, therefore, it is just good business to include women on boards of directors.

While most research has concentrated on firm financial performance, another aspect of firm performance is gaining increased attention. Firm social performance refers to a relatively broad category of actions including illegal activities committed by the firm, firm activities benefiting community or social concerns, protecting the environment, and the like. Uzun, Szewczyk and Varm (2004) is representative of studies in this area, and they found that the number of independent outsiders on a board significantly reduced the incidence of corporate fraud. (A comprehensive list of related studies is available at www.valdosta.edu/ robwill). An overlooked area of research, and the focus of this study, is the role that female directors might play in influencing firm social performance. 


\section{Women On Boards And Firm Social Performance}

Some of the key research that has examined and supports a link between female board membership and firm social performance is presented in Table 1.

Table 1: Relevant Research

\section{Female directors and firm social performance:}

\section{Author(s) and Findings}

Alexander \& Thoits (1985) - Female directors are often viewed as "tokens." It is the absolute number of female directors (tokens) on a board, rather than the proportion of tokens on a board, that is important. The absolute number may be more important, since at some point, there are enough tokens on the board for them to begin to support one another.

Brown, Brown \& Anastasopoulos (2002) - There was a greater likelihood to have conflict-of-interest guidelines and formal codes of conduct within firms with boards having three or more female directors than in firms with all-male boards.

Ibrahim \& Angelidis (1994) - Female directors displayed a stronger orientation toward the discretionary component of corporate social responsibility than male directors, while male directors focused more on the economic performance of the firm than female directors.

Kanter (1977) - A few female board members operate as "tokens." These female tokens are highly visible, and are polarized; characteristics which distinguish the tokens are perceived as highly salient, even if unrelated to task performance. Characteristics of tokens are misperceived to be in line with stereotypes about the token's group. Thus, the only behavior which is accepted from tokens is that which conforms to the stereotype.

Stephenson (2004) - More women on the board results in a major increase in the use of non-financial performance measures, such as innovation and social and community responsibility.

Williams (2003) - Having women on boards of directors was positively related to firms' corporate philanthropy.

\section{Board size and firm performance:}

\section{Author(s) and Findings}

Dalton, Daily, Johnson \& Ellstrand (1999) - Larger boards are more diverse than smaller boards, which encourages conflict and debate, which results in the formation of a wide variety of decision alternatives.

Hermalin \& Weisbach (2003) - Larger boards may experience agency problems, such as director free-loading. In such cases, the board becomes more symbolic, and less a part of the management process.

Jensen (1993) - Smaller boards are better able to monitor firms, since larger boards are more heterogeneous, may function ineffectively, and thus, may be easier for a CEO to control.

Kidwell \& Bennett (1993) - Smaller boards are better able to monitor firms, since there is less social loafing and higher group cohesiveness in smaller boards.

Pearce \& Zahra (1992) - Having more members, a larger board is better equipped to monitor its firm through the establishment of specialized oversight committees.

Williams, Fadil \& Armstrong (In Press) - The incidence of OSHA and EPA violations committed within Fortune 500 firms was significantly reduced in those firms having larger boards. Thus, larger firms are better monitors of firm behavior. 
As stated earlier, one important aspect of firm social performance is illegal activity. Firms are subject to laws designed to protect the public from activities such as accounting fraud, antitrust activities, false advertising, defective and unsafe products, unsafe working conditions, and environmental degradation. Firms that are suspected of having committed such illegal acts are subject to legal proceedings brought by individuals or government agencies. If formally instigated, these investigations are reported on the firm's annual $10 \mathrm{~K}$ report. We propose that if female directors do influence this aspect of firm social performance, this influence should be reflected in the number of $10 \mathrm{~K}$ investigations instigated against the firm. Further, we also suspect that the influence of female directors on the number of $10 \mathrm{~K}$ investigations will be moderated by the average tenure of all board members.

\section{Board Tenure And Firm Performance}

Board tenure, or length of service, is another characteristic of boards of directors which may affect firm performance. There are two competing hypotheses regarding the relationship between board tenure and firm performance (Vafeas, 2003). The "expertise hypothesis" suggests that longer tenure is related to board member experience, commitment, and competence, resulting in better firm financial and social performance. In contrast, the "management friendliness hypothesis" suggests that longer board tenure is associated with a "management-friendly" board. Management friendly boards may lose their objectivity and independence, and have difficulty or be unwilling to monitor management, resulting in lower firm financial and social performance.

In addition to becoming too management-friendly, other disadvantages may accompany long board tenure. Long board tenure may limit cognitive conflict among board members, and may restrict the number of views and opinions that are openly discussed and debated by the board. Daboub, Rasheed, Prien \& Gray (1995) is representative of studies in this area, and they argue that long-tenured board members may lose their ability to recognize and respond to changing environmental conditions. Such heightened conservatism and reduced information processing might encourage "sloppy" management oversight, and may support an environment in which firm misbehavior is more likely to occur. As a result, long-tenured board members may be slow to detect and react to certain legal violations committed within the firm. (A comprehensive list of related studies is available at www.valdosta.edu/ robwill).

However, while the "management friendliness hypothesis" may hold for boards in general, it may be less true of boards having women directors. Women directors may not be fully assimilated into traditionally male dominated boards of directors. There is, for example, evidence that female directors differ from their male counterparts in several ways. Female directors tend to have advanced degrees, and are more likely to come from non-business careers as compared to male directors (Hillman, Cannella \& Harris, 2002). Bilimoria and Piderit (1994) found that male directors were favored for membership on three types of committees: compensation, executive, and finance. On the other hand, female board members were favored for another type of committee, namely public affairs. These results were observed after controlling for the effects of experience.

If, as theory suggests, women are not so readily assimilated into the board as their male counterparts, but rather held at "arms-length" by male board members, the "management-friendliness" hypothesis does not seem appropriate in explaining the influence on firm social performance of female directors. Rather, the "expertise hypothesis" may hold for many female board members. That is, with increased tenure, female board members gain experience, knowledge, and confidence in their ability to influence the firm. Thus, we might expect an interaction effect between the number of women on boards of directors and board tenure.

Hypothesis 1: The number of women on boards of directors will interact with board tenure, such that the higher the number of women and the higher board tenure, the better the social performance of the firm (i.e., the fewer the number of $10 \mathrm{~K}$ investigations), after controlling for the effects of organizational size.

\section{Board Size And Firm Performance}

The research evidence on the effects of board size on firm performance is equivocal. Many researchers propose that larger boards are better able to secure needed resources for their firms, and are better equipped to monitor 
their firms. In contrast, others argue than smaller boards are preferred when it comes to monitoring the firm. Some of the conflicting studies on board size are presented in Table 1. (A comprehensive list of related studies is available at www.valdosta.edu/ robwill).

However, if, as argued earlier, women board members are not fully assimilated into predominately male boards, it may take several women serving on a board before they can create a coalition which has any significant influence on the board. Few women board members serving on very large boards may be able to exercise only minimal influence on board decisions.

Hypothesis 2: The number of women on boards of directors will interact with board size such that the fewer the number of women on boards and the larger the board, the poorer the social performance of the firm (i.e., the greater the number of $10 \mathrm{~K}$ investigations).

\section{METHOD}

Board composition data were gathered from the Edgar database compiled by the Securities and Exchange Commission. The sample firms' 10K Reports and their Def 14A Reports for the years 1998-2002 were the sources of the data. We were able to obtain board data for each firm which included (1) average board size (total number of directors) during the study period, (2) the board composition--insiders versus outsiders, (3) the average tenure of each firm's board during the study period, (4) the number of female board members, and (5) the average number of other boards that each director served on during the study period. Following Alexander and Thoits (1985) (see Table 1), we used the absolute number of women directors, rather than the proportion of women directors, in the analysis.

It was observed that in the vast majority of cases board membership remained fairly stable, with most directors remaining on their firms' boards during the entire study period. All of the variables used in the analysis represent the average of each variable over the five year study period. For example, board tenure was calculated by combining the total number of years of board service of all board members during each year of the study period, and then averaging the result over the five year period.

The average number of each firm's employees during the study period served as the measure of firm size, and was obtained from Hoover's Company Profiles. We selected the number of employees as our size measure, as this measure is used extensively in management research and is fairly well accepted as reflective of firm size. We initially opted to use the logarithm of employees as our size measure, however, our results revealed virtually no difference in the results between using the raw employee data and its logarithmic transformation. Thus, we settled on the total number of firm employees as our size measure.

Both the financial services sector and the basic materials sector of the U.S. economy were selected for study. The basic materials sector was selected because large capital investments are required of firms in this sector and, therefore, the significance of decisions made by boards of directors is extremely high and may involve large capital expenditures. Further, this sector was selected in order to capture the widest possible array of corporate wrongdoing, as firms in this sector involve large scale manufacturing processes and extremely large workforces. The financial services sector was chosen because of the high level of governmental regulation to which firms in this sector are exposed. We were particularly interested in what role board member characteristics might play in boards' ability to monitor firms, even among firms whose conduct is already highly scrutinized by regulators.

Beginning with all firms in the financial services sector and the basic materials sector listed with the SEC between 1998 and 2002, we eliminated all firms not listed on the New York Stock Exchange. Next, we eliminated all firms that did not have at least three 10Ks available in the Edgar database during the study period. For the financial services sector, this resulted in 192 firms drawn from the following industries within this sector; (1) consumer financial services, (2) accident and health insurance, (3) life insurance, (4) property and casualty insurance, (5) investment services, (6) money center banks, (7) regional banks, and (8) savings banks. For the basic materials sector, this resulted in 124 firms from such industries as (1) chemical manufacturing, (2) plastic and rubber, (3) containers 
and packaging, (4) iron and steel, (5) paper and paper products, (6) gold and silver, (7) forestry and wood products, (8) metal mining, (9) miscellaneous fabricated products, and (10) non-metallic mining.

\section{K Investigations}

A measure of firm social performance, the number of investigations initiated against each firm, was obtained from the SEC Edgar database. A detailed description of these investigations is presented in Item 3 of each firm's 10K Reports. The number of $10 \mathrm{~K}$ investigations was selected as a measure of firm social performance as these investigations reflect possible corporate misbehavior, and reflect how well firms are being monitored by their boards. Only those investigations conducted between 1998 and 2002 were included. The possible types of misbehavior for which firms are investigated are frequently very serious in nature, and involve legal proceedings well beyond the firm's ordinary business activity.

In analyzing the $10 \mathrm{~K}$ reports, two raters were used to categorize the types and timing of the various investigations. In the vast majority of cases, the raters were in agreement as to the nature and time period in which the investigations were undertaken. In the few cases where agreement could not be reached, a third rater was used to settle the issue.

\section{Results}

Table 2 presents descriptive statistics and a correlation matrix for each sector.

Table 2: Descriptive Statistics And Correlation Matrices By Sector

\begin{tabular}{|c|c|c|c|c|c|c|c|}
\hline \multicolumn{8}{|c|}{ Financial Services Sector $(\mathrm{N}=192)$} \\
\hline Variable & Mean & SD & 1 & 2 & 3 & 4 & 5 \\
\hline 1. Firm Size & 12169 & 25985 & 1.00 & $.40 * *$ & .10 & $.37 * *$ & $.35 * *$ \\
\hline 2. Women & .94 & .89 & & 1.00 & $.15^{*}$ & $.13 *$ & $.45^{* *}$ \\
\hline 3. Board Tenure & 99.42 & 59.31 & & & 1.00 & $-.21 * *$ & $.57 * *$ \\
\hline 4. $10 \mathrm{~K}$ Investigations & 2.06 & 3.63 & & & & 1.00 & .03 \\
\hline 5. Board Size & 11.74 & 4.06 & & & & & 1.00 \\
\hline \multicolumn{8}{|c|}{ Basic Materials Sector $(\mathrm{N}=124)$} \\
\hline Variable & Mean & SD & 1 & 2 & 3 & 4 & 5 \\
\hline 1. Firm Size & 10060 & 18773 & 1.00 & $.42 * *$ & $.19 *$ & $.27 * *$ & $.36^{* *}$ \\
\hline 2. Women & .73 & .71 & & 1.00 & $.41 * *$ & .14 & $.62 * *$ \\
\hline 3. Board Tenure & 75.95 & 47.63 & & & 1.00 & -.03 & $.55 * *$ \\
\hline 4. $10 \mathrm{~K}$ Investigations & 1.25 & 1.95 & & & & 1.00 & .04 \\
\hline 5. Board Size & 9.31 & 2.43 & & & & & 1.00 \\
\hline
\end{tabular}

$* \mathrm{p}<.05, * * \mathrm{p}<.01$

It was observed that the mean total years of service for the boards in the basic materials sector was 75.95 years $(\mathrm{sd}=47.63)$. There was a mean of $6.60(\mathrm{sd}=2.37)$ outside board members, a mean total board size of $9.31(\mathrm{sd}$ $=2.43$ ), and .73 board members, on average, were women. The range in female board members was 0 to 3 members. Also, total board size within the basic materials sector ranged from 4 to 16 members. The mean number of employees for firms in this sector was 10,060 ( $\mathrm{sd}=18773$ ), with firm size ranging from a low of 295 employees to a high of 121 , 840 employees. Finally, the mean number of $10 \mathrm{~K}$ investigations for firms in this sector was $1.25(\mathrm{sd}=1.95)$.

In the financial services sector, the mean total years of service for the boards was 99.42 years $(\mathrm{sd}=59.31)$. There was a mean of $8.73(\mathrm{sd}=3.82)$ outside board members, a mean total board size of $11.74(\mathrm{sd}=4.06)$, and .94 members, on average, were women. The range in female board members for this sector was 0 to 4 members. Total board size ranged from 5 to 25 members. The mean number of employees for firms in this sector was $12169(\mathrm{sd}=$ 
25985 ), with a range of 106 employees to 214,350 employees. The mean number of $10 \mathrm{~K}$ investigations for these firms was $2.06(\mathrm{sd}=3.63)$.

An anova of $10 \mathrm{~K}$ investigations by sector was conducted to determine whether the data from the two sectors might be combined. The financial services sector experienced significantly more $10 \mathrm{~K}$ investigations per firm $($ mean $=$ 2.06) than the basic materials sector (mean $=1.25)(\mathrm{F}=6.17, \mathrm{p}<.05)$. Therefore, data from the two sectors were analyzed separately.

Data from each sector were submitted to a moderated regression analysis of $10 \mathrm{~K}$ investigations on women and total board tenure, controlling for the effects of firm size (average number of employees). Firm size was entered on step one of the regression, followed by the number of women on the board and total board tenure. Finally, a twoway interaction term (the product of the number of women on the board and total board tenure) was entered on step 3 . A significant increase in explained variance at step 3 indicates an interaction between the two independent variables.

Table 3 presents the results of the moderated regression analysis for Hypothesis 1.

Table 3: Results Of The H1 Moderated Regression Analysis

\begin{tabular}{lcc}
\hline & $\begin{array}{l}\text { Financial Services Firms (N=192) } \\
\text { Incremental Change in } \mathbf{R}^{\mathbf{2}}\end{array}$ & $\begin{array}{l}\text { Basic Materials Firms (N=124) } \\
\text { Incremental Change in } \mathbf{R}^{\mathbf{2}}\end{array}$ \\
Organizational Size & $.140^{* *}$ & $.073 * *$ \\
Women, Board Tenure & $.063 * *$ & .011 \\
Women X Tenure & $.023^{*}$ & .001 \\
Model $\mathrm{R}^{2}$ & $.23 * *$ & .086 \\
\hline${ }^{\mathrm{p}}<.05, * * \mathrm{p}<.01$ & &
\end{tabular}

As Table 3 indicates, there was a significant two-way interaction between the number of women on the board and total board tenure for firms in the financial services sector. The interaction explained an additional $2 \%$ of the variance in the number of $10 \mathrm{~K}$ investigations. To interpret this interaction, these two independent variables were split at their respective means to create a categorical variable with four categories (fewer women on board, lower total board tenure; fewer women on board, higher total board tenure; more women on board, lower total board tenure; more women on board, higher total board tenure. The categorical variable was then used in an ANOVA of 10K investigations. Least Significant Difference (LSD) post hoc tests revealed three significant differences among these groups, as shown in Table 4.

Table 4: Results Of The LSD Post Hoc Tests For Financial Services Sector Firms

\begin{tabular}{|c|c|c|c|c|c|}
\hline & 1 & 2 & 3 & $\mathbf{n}$ & Mean \\
\hline 1 & & & $*$ & 56 & 1.9464 \\
\hline 2 & & & & 29 & .8966 \\
\hline 3 & $(*)$ & & & 57 & 3.8596 \\
\hline 4 & & & $*$ & 50 & .8000 \\
\hline \multicolumn{6}{|c|}{ Groups significantly different at $\mathrm{p}<.05$ indicated by $*$ in table. Parentheses indicate a redundant significant difference } \\
\hline 1. & Fewer women on board & ard & & & \\
\hline 2. & Fewer women on board & & & & \\
\hline 3. & More women on board, & $\operatorname{ard}$ & & & \\
\hline 4. & More women on board, & ard & & & \\
\hline
\end{tabular}


As Table 4 indicates, firms with more women on the board and lower total board tenure experienced significantly more $10 \mathrm{~K}$ investigations than firms with fewer women on the board and lower total board tenure, and firms with more women on the board and higher board tenure. The significant difference between groups 3 and 4 indicates that when a firm has more women on the board, higher board tenure results in significantly fewer $10 \mathrm{~K}$ investigations, supporting Hypothesis 1. The significant difference between groups 1 and 3 indicates that firms with relatively low total board tenure experience significantly greater numbers of $10 \mathrm{~K}$ investigations when the number of women on the board increases. This interaction is plotted in Figure 1.

Figure 1: Plot Of Significant Two-Way Interaction, Number Of Women On The Board X Total Board Tenure

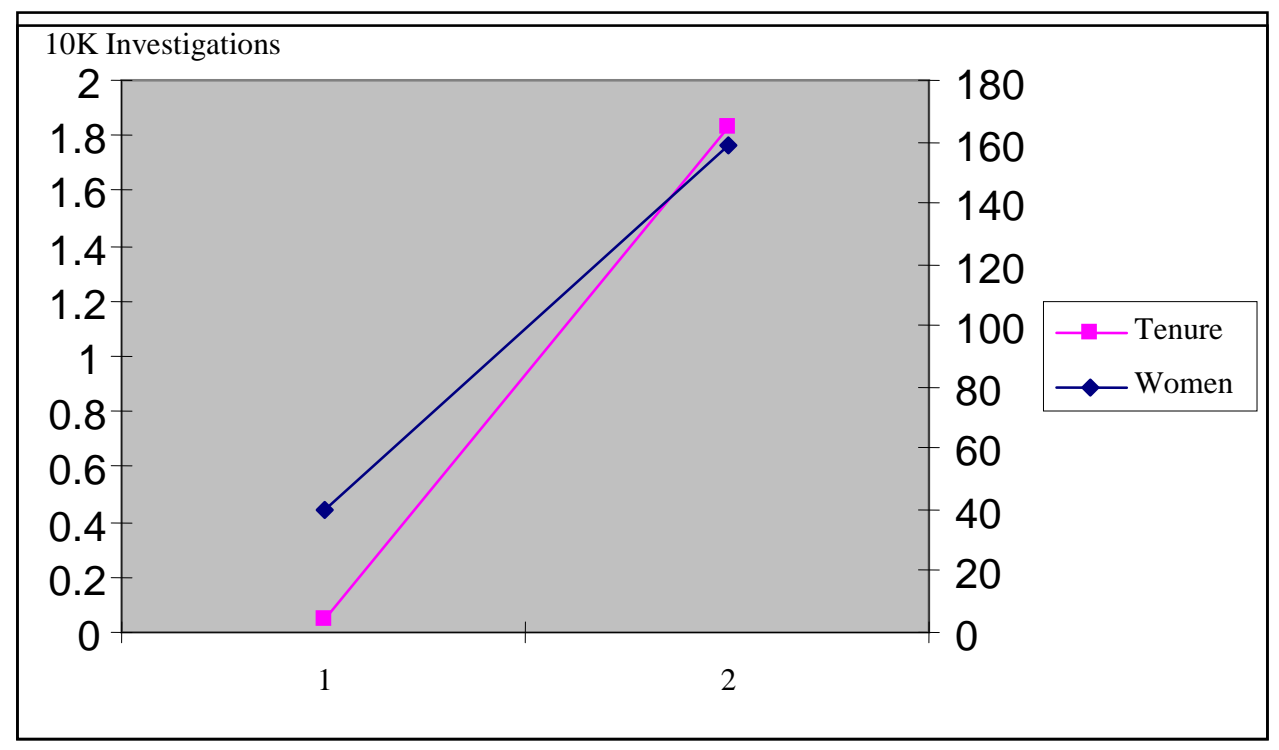

As can be seen in Table 3, there was no significant two-way interaction effect among the firms in the basic materials sector. In addition, neither the number of women on the board nor total board tenure explained any additional variance beyond the control variable (organizational size). Table 2 shows a positive bivariate correlation of $.42(\mathrm{p}<.01)$ between organizational size and the number of $10 \mathrm{~K}$ investigations. Thus, in this sector, the larger the firm, the greater the number of $10 \mathrm{~K}$ investigations.

Hypothesis 2 predicted an interaction effect between the number of women board members and board size, such that the fewer the number of women on boards and the larger the board, the poorer the social performance of the firm (i.e., the greater the number of $10 \mathrm{~K}$ investigations). The results of the regression analysis testing this hypothesis appear in Table 5.

Table 5: Results Of The H2 Moderated Regression Analysis

\begin{tabular}{lcc}
\hline & $\begin{array}{l}\text { Financial Services Firms (N=192) } \\
\text { Incremental Change in } \mathbf{R}^{\mathbf{2}}\end{array}$ & $\begin{array}{c}\text { Basic Materials Firms (N=124) } \\
\text { Incremental Change in } \mathbf{R}^{2}\end{array}$ \\
Organizational Size & $.138^{* *}$ & $.073^{* *}$ \\
Women, Board Size & .012 & .011 \\
Women X Board Size & .001 & .001 \\
Model $\mathrm{R}^{2}$ & .11 & .085 \\
\hline$* \mathrm{p}<05, * * \mathrm{p}<01$ & &
\end{tabular}

$* \mathrm{p}<.05, \quad * * \mathrm{p}<.01$ 
As Table 5 indicates, Hypothesis 2 was not supported for the firms in either sector. There was no significant interaction between the number of women on boards of directors of firms in these sectors and board size.

\section{DISCUSSION}

The results suggest that the number of women on a firm's board does moderate the effect of board tenure on the firm's level of social performance. Our findings provide some evidence that the inclusion of more women on a board which has relatively low tenure is associated with an increase in the number of $10 \mathrm{~K}$ investigations. Boards with a relatively higher number of women members experience fewer $10 \mathrm{~K}$ investigations when the board has higher tenure, compared to boards with relatively fewer women.

Perhaps this is a result of fragmentation of boards of directors. If women are not readily assimilated into male dominated boards, but rather kept at arms length by their male colleagues, this may impede board monitoring and control effectiveness. Or, it may be that, over time, women are readily assimilated into boards of directors. In such situations, the management-friendliness orientation of a board may be increased.

It should be noted, however, that although the interactive pattern observed between women and board tenure was present among the financial services firms, no such interaction effect was observed among the basic materials firms. While we can only speculate as to why this was observed, two possible explanations present themselves. First, financial services firms may operate in a far more dynamic environment than the relatively stable environment faced by basic materials firms. The manufacturing of basic materials involves large capital investments in plant and equipment. Once major decisions regarding large scale production infrastructure and strategic direction have been made, it may be very difficult and expensive for firms to change or significantly alter their courses. For basic materials firms, board decisions may become more routine once major decisions are reached, reducing the impact of women directors on firm financial and social performance.

In contrast, financial services firms rely upon their ability to gather, process and act on information about their customers, and to adapt to the changing financial needs of their customers. It may be that board decisions involve fewer routine matters, and stress more ongoing monitoring and oversight functions in financial firms. The diversity of a board containing female board members, who may possess a slightly different knowledge base and, on average, more advanced academic training than their male counterparts, may be more evident in such firms.

A second rationale for our findings may result from the different degrees of regulation that may exist between the two sectors. It seems logical to assume that financial services firms might face far more stringent government oversight than firms in other sectors. In order to ensure public confidence, government regulators must preserve the integrity of financial services firms, and this is accomplished through extensive regulation and supervision. In fact, given the greater number of regulations faced by financial firms, "crimes" of omission rather than commission may actually be more prevalent among financial firms. In such a highly regulated environment, boards must be vigilant, and the need for open debate and discussion that emerges out of cognitive conflict would be valuable tools for financial firms.

The failure to find an interactive link between women and board size for either sector was surprising. We believe that a "threshold" effect might be present here. For women to have a significant impact on firm behavior in larger boards, a voting block of two or more women directors might be necessary. Among our sample firms, we noted that $70 \%$ of the financial firms and $79 \%$ of the basic material firms had boards with either none or only one women director. We can only surmise that below some threshold, too few women may have no significant impact on firm social performance.

It is significant that the findings differed across the two sectors of the economy. Few studies have considered the effects of board characteristics on firm performance by sector or industry. While careful not to overstate the implications of our findings, the present study does serve to broaden our understanding of proper corporate governance, and highlights a potential weakness in many prior studies in this area. We have provided some evidence that the relationships between board characteristics and firm social performance are not generalizable from one sector 
to another. Rather, like many other areas of research, board characteristics research may benefit from a "contingency approach." Future research should take into account these potential sector or industry effects, and carefully consider how the industry may suppress, neutralize, or otherwise affect the impact of board characteristics on firm performance.

In conducting this study, several limitations became evident. By using the total number of investigations as reported in the firms' $10 \mathrm{~K}$ Reports, differences in the magnitude of investigations were not taken into account. Obviously, investigations involving less serious violations might be committed more often than more serious violations. While the dependent variable, "investigations," was used to measure firm social performance, it may be more reflective of "sloppy" management oversight. At any rate, the responsibility for correcting inadequate management oversight must ultimately rest with the board. Future studies in this area might consider a more precise measure of social performance than was used in this study.

While overall board tenure was examined, the tenure of women directors and its impact on their firms' boards was not considered. Once appointed to the board, it may take some time before women feel comfortable in their roles as directors. Their full impact on board decision making may not be evident for some time. While beyond the scope of this study, future research might examine this issue.

The use of average data over a five year time period is a limitation. This obviously ignores any potential fluctuations in the variables over time. Future research may consider the possible effects of time. Perhaps there is a delay between the time the board takes some action and its ultimate effects on both firm financial and social performance.

Overall, this study should add to our understanding of corporate governance. Future research that examines how various board characteristics, including gender, interact with other board characteristics is strongly encouraged. The authors are aware of no prior studies that have examined such interactive patterns, nor the role that the firm's sector or industry might play in influencing these variables. These issues offer fertile ground for future research.

\section{REFERENCES}

1. Alexander, V. D. and P. A Thoits, Token Achievement: An Examination of Proportional Representation and Performance Outcomes, Social Forces, Vol. 64, No. 2, pp. 332-340, 1985.

2. Bilimoria, D. and S. K. Piderit, Board Committee Membership: Effects of Sex-Based Bias, Academy of Management Journal, Vol. 37, No. 6, pp. 1453-1477, 1994.

3. Brown, D. A., D. L. Brown, and V. Anastasopoulos, Women on Boards: Not Just the Right Thing ... But the 'Bright' Thing, May 2002, Conference Board of Canada.

4. Burgess, Z. and P. Tharenou, Women Board Directors: Characteristics of the Few, Journal of Business Ethics, Vol. 37, No. 1, pp. 39-49, 2002..

5. $\quad$ Catalyst, Women Board Directors of the Fortune 500, Catalyst, New York, 1998.

6. Daboub, A. J., A. M. Rasheed, R. L. Priem, and A. Gray, Top Management Team Characteristics and Corporate Illegal Activity, Academy of Management Review, Vol. 20, No. 1, pp. 138-170, 1995.

7. Daily, C. M., S. T. Certo, and R. Dalton, A Decade of Corporate Women: Some Progress in the Boardroom, None in the Executive Suite, Strategic Management Journal, Vol. 29, No. 1, pp. 93-99, 1999.

8. Dalton, D. R., C. M. Daily, J. L. Johnson, and A. E. Ellstrand, Number of Directors and Financial Performance: A Meta-Analysis, Academy of Management Journal, Vol. 42, No. 6, pp. 674-686, 1999.

9. Hermalin, B. and M. Weisbach, Boards of Directors as an Endogenously Determined Institution: A Survey of the Economic Literature, Economic Policy Review, Federal Reserve Bank of New York, Vol. 9, No. 1, pp. 726.

10. Hillman, A. J., A. A. Cannella, Jr., and I. C. Harris, Women and Racial Minorities in the Boardroom: How do Directors Differ? Journal of Management, Vol. 28, No. 6, pp. 747-763, 2002.

11. Ibrahim, N. A. and J. P. Angelidis, Effect of Board Members' Gender on Corporate Social Responsiveness Orientation, Journal of Applied Business Research, Vol. 10, No. 1, pp. 35-40, 1994. 
12. Jensen, M., The Modern Industrial Revolution, Exit, and the Failure of Internal Control Systems, Journal of Finance, Vol. 48, No. 3, pp. 831-880, 1993.

13. Kanter, R. M., Some Effects of Proportions on Group Life: Skewed Sex Ratios and Responses to Token Women, American Journal of Sociology, Vol.82, No. 5, pp. 965-990, 1977.

14. Kidwell, R. E. and N. Bennett, Employee Propensity to Withhold Effort: A Conceptual Model to Intersect Three Avenues of Research, Academy of Management Review, Vol. 18, No. 3, pp. 429-456, 1993.

15. Pearce, J. A. and S. A. Zahra, Board Composition From a Strategic Contingency Perspective, Journal of Management Studies, Vol. 29, No. 4, pp. 411-438, 1992.

16. Stephenson, C., Leveraging Diversity to Maximum Advantage: The Business Case for Appointing More Women to Boards, Ivey Business Journal, Vol. 69, No. 1, pp. 1-5, 2004.

17. Uzun, H., S. H. Szewczyk, and R. Varma, Board Composition and Corporate Fraud, Financial Analysts Journal, Vol. 60, No. 3, pp. 33-43, 2004.

18. Vafeas, M., Length of Board Tenure and Outside Director Independence, Journal of Business Finance and Accounting, Vol. 30, No. 7, pp. 1043-1064, 2003.

19. Williams, R. J., Women on Corporate Boards of Directors and Their Influence on Corporate Philanthropy, Journal of Business Ethics, Vol. 42, No. 1, pp. 1-10, 2003.

20. Williams, R. J., P. A. Fadil, and R. W. Armstrong, Top Management Team Tenure and Corporate Illegal Activity: The Moderating Influence of Board Size, Journal of Managerial Issues, In Press.

\section{NOTES}

